\title{
Awareness and Attitude Towards the Premarital Screening Programme Among High School Students in Muscat, Oman
}

"Rahma M. Al-Kindi, ${ }^{1}$ Saraswathi Kannekanti, ${ }^{2}$ Jansi Natarajan, ${ }^{3}$ Lina Shakman, ${ }^{4}$ Zeinab Al-Azri, ${ }^{4}$ Naifain I. Al-Kalbani

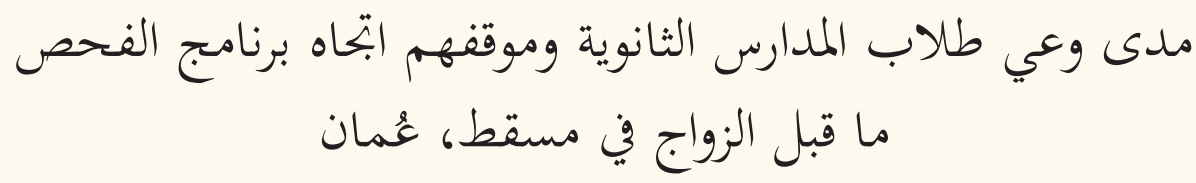

رحمة محمد الكندية، ساراسواثي كانيكانتي، جانسي ناتاراجان، لينا شاكمان، زينب العزرية، نيفين إبراهيم الكلبانية

ABSTRACT: Objectives: This study aimed to explore high school students' awareness and attitude towards premarital screening (PMS). Methods: This cross-sectional study was conducted in 10 public high schools in Muscat, Oman from May to July 2016. A three-part self-administered questionnaire was used to collect data from grade 12 students. The first part focused on respondents' sociodemographic characteristics, while the second part dealt with awareness of the national PMS programme and the third part explored attitudes towards the national PMS programme. Results: A total of 1,541 participants (response rate: $91.1 \%)$ completed the questionnaire. Most participants (78.1\%) were aware of the availability of the PMS programme and their main source of information was family and friends (34.3\%). The majority of students (87.4\%) believed that PMS is important and most students (87.2\%) indicated that they would undergo PMS. Over half of the students (55.3\%) agreed that PMS should be mandatory before marriage and approximately one-third (38.3\%) were in favour of having laws and regulations to prevent consanguineous marriages. Females were significantly more in favour of making PMS mandatory $(P=0.002)$ and enforcing PMS laws $(P=0.010)$ compared to males. Conclusion: Most respondents had good levels of knowledge about the PMS programme and half thought it is important to be tested. However, some students were not in favour of PMS. Increasing awareness about Oman's PMS programme is important and motivating students could contribute significantly to increasing the utilisation of the PMS programme and to limiting genetic blood disorders.

Keywords: Awareness; Knowledge; Attitude; Secondary School; Students; Premarital Examinations; Genetic Carrier Screening; Oman.

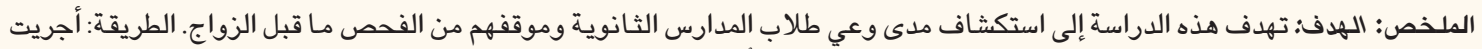

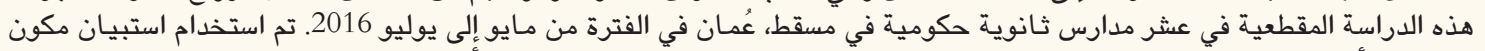

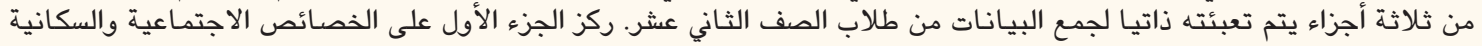

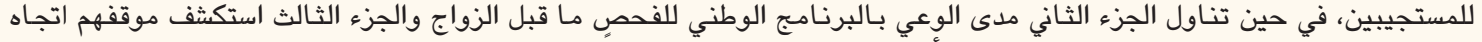

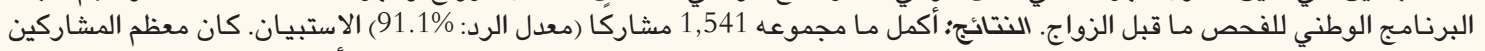

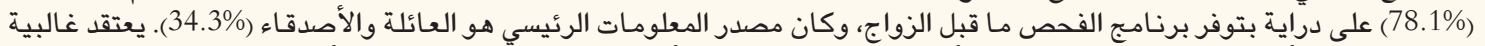

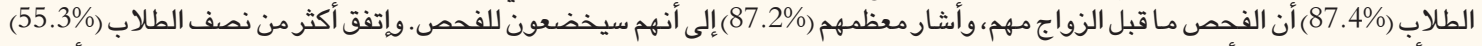

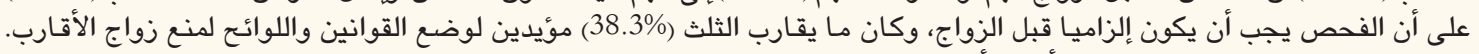

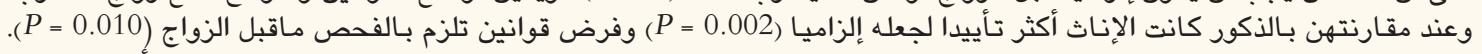

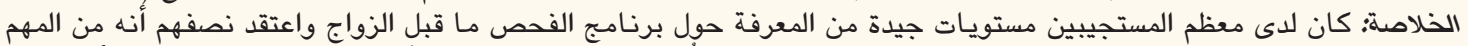

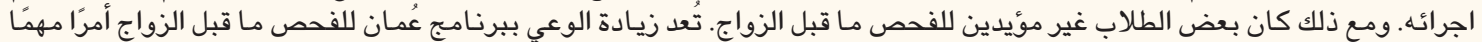

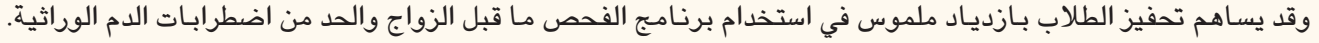

الكلمات المفتاحية: وعي؛ معرفة؛ موقف؛ مدرسة ثانوية؛ طلاب؛ فحص ما قبل الزواج؛ فحص الناقل الوراثي؛ عُمان.

\section{Advances in KNOWLedge}

This study found that high school students are willing to follow premarital screening (PMS) policies, suggesting support for modifying laws around PMS.

This study suggests recommendations to improve PMS utilisation and efficacy in Oman.

\section{Application to Patient Care}

PMS should be promoted through a health education campaign that stresses the availability of the programme and its importance in decreasing the burden of genetic blood disorders.

Healthcare providers should encourage the target population to take advantage of PMS.

Students and young adults should be motivated to utilise PMS services.

Departments of ${ }^{1}$ Family Medicine \& Public Health, ${ }^{2}$ Community \& Mental Health, ${ }^{3}$ Fundamentals \& Administration and ${ }^{4}$ Maternal \& Child Health, Sultan Qaboos University, Muscat, Oman; ${ }^{5}$ Department of Child Health, Royal Hospital, Muscat, Oman

*Corresponding Author's e-mail: rkindi@squ.edu.om 
G ENETIC BLOOD DISORDERS ARE COMMON in the Arab world and are responsible for major physical and mental disabilities. ${ }^{1}$ According to the World Health Organization, 28\% of deaths in children below five years of age in Oman are due to inherited blood disorders. ${ }^{2}$ The most common inherited blood disorders are glucose-6-phosphate dehydrogenase (G6PD) deficiency, thalassaemia and sickle cell anaemia. ${ }^{3}$ G6PD enzyme deficiency had the highest prevalence in the 2003 Genetic Blood Disorders Survey in Oman, with $25 \%$ of males and $10 \%$ of females affected. In the same survey, the prevalence of the sickle cell trait was $6 \%$ and the beta-thalassaemia trait was $2 \%$, while the prevalence of sickle cell disease was $0.2 \%$ and homozygous betathalassaemia was $0.07 \%$. Oman has an annual increase of 120 cases of sickle cell disease and 18-20 cases of the beta-thalassaemia trait. ${ }^{4}$

Consanguinity is very common in Oman as embedded beliefs, customs and traditions reinforce high rates of consanguinity. In total, 39\% of Omanis are married to their first cousins; Oman ranks among the top seven Arab countries in terms of consanguinity rates., ${ }^{5,6}$ Consanguineous marriages can result in increased expression of autosomal recessive disorders. ${ }^{7}$

These hereditary blood disorders are a major concern to the Ministry of Health $(\mathrm{MOH})$ as they represent a considerable economic burden on the healthcare system. In response to the high prevalence of these disorders, the $\mathrm{MOH}$ initiated the Premarital Screening (PMS) and Counselling Programme in 2001 as a cost-effective preventative measure to reduce the incidence of inherited blood disorders. This programme involves clinical assessment and blood investigations for G6PD enzyme activity and haemoglobin electrophoresis to screen for genetic blood disorders. Relevant health education and genetic counselling are important pillars of this programme. ${ }^{8}$ Currently, the PMS programme is not mandatory in Oman and is provided on a voluntary and individual basis.

Although the PMS programme was introduced in Oman in 2001, its utilisation remains low. ${ }^{8,9}$ According to $2014 \mathrm{MOH}$ statistics, Oman's estimated level of PMS programme utilisation is $10 \% .^{9}$ However, several other screening programmes in Gulf Cooperation Council (GCC) and Mediterranean countries have been very effective. In Iran, the incidence of thalassaemia has been reduced by $70 \%$ and in Lebanon the incidence was comparably decreased by $75 \%$ as a result of PMS programmes. ${ }^{10,11}$ Despite introducing PMS in most GCC countries, only Bahrain has had a 60\% reduction in the incidence of thalassaemia, which could be due to its laws that prevent marriage in cases of positive screening tests. ${ }^{12}$ Oman might benefit equally by legally stopping marriages in cases of positive screening test results.

Many studies have been conducted in Oman addressing PMS awareness. A study among university students revealed that $79 \%$ of participants were aware of the availability of Oman's PMS programme; the vast majority of participants (92\%) acknowledged its importance and agreed to undergo the screening. ${ }^{13}$ Another study among adults attending primary healthcare centres found that $89.3 \%$ of participants were aware of the PMS programme, of which $84.5 \%$ believed that premarital counselling is necessary. ${ }^{14}$ Both studies showed that approximately half of the participants were in favour of making PMS mandatory.

Studies in the region have revealed a lack of knowledge of premarital testing. ${ }^{13-18}$ Informal interviews with high school teachers and school nurses have confirmed the infrequency of in-school instruction around Oman's PMS programme. Furthermore, high school students may not have enough knowledge about genetic disorders to realise the potential of PMS in reducing such disorders. Therefore, it is important that this group be empowered with knowledge intended to ultimately reduce the incidence of inherited blood disorders. Hence, this study aimed to explore the current knowledge and attitudes towards Oman's PMS programme among high school students with the intention of influencing methods of effective implementation of such an important programme.

\section{Methods}

This cross-sectional study was conducted at 10 public high schools in Al-Seeb area of Muscat Governorate from May to July 2016. These schools had approximately 2,100 grade 12 students distributed among 70 classes. Students were excluded if they were absent from school during the study period, refused to participate or had learning difficulties that made the independent completion of the questionnaire difficult.

A validated, pre-tested and well-structured questionnaire with closed-ended questions on PMS was used to collect data. This questionnaire had been used in a previous study and permission was obtained from the authors to use the tool with minimal modifications to questions associated with demographic information. ${ }^{13}$ The questionnaire was divided into three parts: part one focused on participants' sociodemographic characteristics (gender, age, parents' consanguinity and personal and family histories of existing inherited blood disorders); part two explored students' knowledge and awareness of PMS (its availability in Oman, sources of information about PMS, components of the screening, who can be tested and which diseases it targets); and part three 
questioned the respondents' attitudes towards Oman's PMS programme.

This study was conducted during school hours and the Arabic version of the questionnaire was distributed to all participants by trained research assistants. The researchers explained the aims of the study to each class and were available to assist with any inquiries. Each class required approximately 20 minutes to complete the questionnaire which was followed by a brief introduction on Oman's PMS programme.

Statistical Package for Social Sciences (SPSS), Version 23 (IBM, Corp., Armonk, New York, USA) was used for data entry and analysis. All participants who indicated 'did not know' for a question were excluded from the analysis of that variable. Students with missing data were excluded from the statistical analysis for some variables. Descriptive statistics were used to describe the sample's characteristics and frequencies and percentages were reported for categorical variables. Pearson's chi-squared test or Fisher's exact test for cells less than five were used to test significance when appropriate. A $P$ value of $\leq 0.05$ was considered statistically significant.

Participation was voluntary and written informed consent was obtained prior to data collection. All participants were informed about their right to withdraw from the study at any time and their anonymity and confidentiality were assured and emphasised. Ethical approval for the study was granted by the College of Nursing Medical Research and the Ethics Committee, Sultan Qaboos University, Muscat, Oman, in March 2015. Official permission to distribute the questionnaires was obtained from the Directorate General of Education Muscat Region, Ministry of Education, Oman.

\section{Results}

A total of 1,541 students completed the questionnaire (response rate: 91.1\%). All respondents were unmarried, the majority were Omani (96\%) and male (55.4\%). The mean age was $17.7 \pm 0.8$ years (range: $16-20$ years) [Table 1].

A personal history and a family history of hereditary diseases were reported by $8.2 \%$ and $28.8 \%$ of respondents, respectively. More than one-third of the participants (39.6\%) reported that their parents were related where some indicated that their parents were first (25\%) or second (14.6\%) cousins. The rest of the respondents reported distant or no familial relationship between their parents.

Most students (78.1\%) were aware of the availability of the PMS programme in Oman. The main source of information about the PMS programme were family and friends (34.4\%) followed by school subjects (30.3\%),
Table 1: Characteristics of high school students who participated in this study $(\mathrm{N}=1,541)$

\begin{tabular}{|c|c|c|c|c|}
\hline \multirow[t]{2}{*}{ Characteristic } & \multicolumn{3}{|c|}{ n (\%) } & \multirow{2}{*}{$\begin{array}{c}P \\
\text { value }\end{array}$} \\
\hline & Total & $\begin{array}{c}\text { Male } \\
(\mathrm{n}=853)\end{array}$ & $\begin{array}{c}\text { Female } \\
(n=688)\end{array}$ & \\
\hline \multicolumn{5}{|c|}{ Personal history of hereditary disease } \\
\hline Yes & $\begin{array}{l}126 \\
(8.2)\end{array}$ & $\begin{array}{c}58 \\
(6.8)\end{array}$ & $\begin{array}{c}68 \\
(9.9)\end{array}$ & \multirow{3}{*}{0.047} \\
\hline No & $\begin{array}{l}1,204 \\
(78.1)\end{array}$ & $\begin{array}{c}671 \\
(78.7)\end{array}$ & $\begin{array}{c}533 \\
(77.5)\end{array}$ & \\
\hline Don't know & $\begin{array}{c}211 \\
(13.7)\end{array}$ & $\begin{array}{c}124 \\
(14.5)\end{array}$ & $\begin{array}{c}87 \\
(12.6)\end{array}$ & \\
\hline \multicolumn{5}{|c|}{ Family history of hereditary disease } \\
\hline Yes & $\begin{array}{c}444 \\
(28.8)\end{array}$ & $\begin{array}{c}187 \\
(21.9)\end{array}$ & $\begin{array}{c}257 \\
(37.4)\end{array}$ & \multirow{3}{*}{$<0.001$} \\
\hline No & $\begin{array}{c}717 \\
(46.5)\end{array}$ & $\begin{array}{c}472 \\
(55.3)\end{array}$ & $\begin{array}{c}245 \\
(35.6)\end{array}$ & \\
\hline Don't know & $\begin{array}{c}380 \\
(24.7)\end{array}$ & $\begin{array}{c}194 \\
(22.7)\end{array}$ & $\begin{array}{l}186 \\
(27)\end{array}$ & \\
\hline \multicolumn{5}{|c|}{ Consanguineous relationship between parents } \\
\hline Yes & $\begin{array}{c}626 \\
(40.6)\end{array}$ & $\begin{array}{c}379 \\
(44.4)\end{array}$ & $\begin{array}{c}247 \\
(35.9)\end{array}$ & \multirow{3}{*}{$<0.001$} \\
\hline No & $\begin{array}{c}790 \\
(51.3)\end{array}$ & $\begin{array}{c}388 \\
(45.5)\end{array}$ & $\begin{array}{c}402 \\
(58.4)\end{array}$ & \\
\hline Don't know & $\begin{array}{l}125 \\
(8.1)\end{array}$ & $\begin{array}{c}86 \\
(10.1)\end{array}$ & $\begin{array}{c}39 \\
(5.7)\end{array}$ & \\
\hline \multicolumn{5}{|c|}{ Type of relationship between parents } \\
\hline $\begin{array}{l}\text { First-degree } \\
\text { cousins }\end{array}$ & $\begin{array}{l}386 \\
(25)\end{array}$ & $\begin{array}{c}229 \\
(62.1)\end{array}$ & $\begin{array}{c}157 \\
(64.9)\end{array}$ & \multirow{3}{*}{0.535} \\
\hline $\begin{array}{l}\text { Second-degree } \\
\text { cousins }\end{array}$ & $\begin{array}{c}225 \\
(14.6)\end{array}$ & $\begin{array}{c}140 \\
(37.9)\end{array}$ & $\begin{array}{c}85 \\
(36.1)\end{array}$ & \\
\hline $\begin{array}{l}\text { Distant or } \\
\text { no familial } \\
\text { relationship }\end{array}$ & $\begin{array}{c}930 \\
(60.4)\end{array}$ & $\begin{array}{c}484 \\
(56.7)\end{array}$ & $\begin{array}{c}446 \\
(64.8)\end{array}$ & \\
\hline
\end{tabular}

media and newspaper reports (18.5\%) and healthcare services and school nurses (16.8\%). The vast majority of students (92.8\%) knew that the screening test should involve both partners. Some students (40.2\%) knew that the PMS programme includes blood tests and physical examinations while others thought it only includes blood tests (33.4\%). The majority of participants (59.8\%) thought that the PMS programme targets genetic blood disorders as well as sexually transmitted diseases (STDs); however, some thought that it tests only genetic blood disorders (17.8\%) or only STDs (9.7\%) [Table 2].

The majority of students $(87.4 \%)$ thought that carrying out PMS is important and a similar number of students (87.2\%) agreed to undergo the PMS tests. The respondents' reasons for agreeing to PMS testing were to prevent transmission of diseases to their offspring (73.4\%), ensure that their partner is healthy (43.6\%), protect themselves from diseases (25.3\%) and confirm their fitness for marriage (19.1\%). 
Table 2: Knowledge of high school students about Oman's premarital screening programme $(\mathrm{N}=1,541)$

$\begin{array}{lcccc}\begin{array}{l}\text { Knowledge } \\ \text { item }\end{array} & \text { n (\%) } & & \begin{array}{c}P \\ \text { value }\end{array} \\ & \text { Total } & \begin{array}{c}\text { Male } \\ (\mathrm{n}=853)\end{array} & \begin{array}{c}\text { Female } \\ (\mathrm{n}=688)\end{array} & \end{array}$

Is a PMS programme available in Oman?

$\begin{array}{lcccc}\text { Yes } & 1,204 & 627 & 577 & \\ & (78.1) & (73.5) & (83.9) & \\ \text { No } & 58 & 43 & 15 & 0.002 \\ & (3.8) & (5.0) & (2.2) & \\ \text { Don't know* } & 279 & 183 & 96 & \\ & (18.1) & (21.5) & (14.0) & \end{array}$

Source of information about PMS programme $(n=1,200)^{\dagger}$

\begin{tabular}{|c|c|c|c|c|}
\hline $\begin{array}{l}\text { Family and } \\
\text { friends }\end{array}$ & $\begin{array}{c}413 \\
(34.4)\end{array}$ & $\begin{array}{c}213 \\
(34.1)\end{array}$ & $\begin{array}{c}200 \\
(34.7)\end{array}$ & \multirow{4}{*}{0.180} \\
\hline $\begin{array}{l}\text { School } \\
\text { subjects }\end{array}$ & $\begin{array}{c}364 \\
(30.3)\end{array}$ & $\begin{array}{l}175 \\
(28)\end{array}$ & $\begin{array}{c}189 \\
(32.8)\end{array}$ & \\
\hline $\begin{array}{l}\text { Media and } \\
\text { newspapers }\end{array}$ & $\begin{array}{c}222 \\
(18.5)\end{array}$ & $\begin{array}{c}126 \\
(20.2)\end{array}$ & $\begin{array}{c}96 \\
(16.7)\end{array}$ & \\
\hline $\begin{array}{l}\text { Healthcare } \\
\text { services } \\
\text { and school } \\
\text { healthcare } \\
\text { nurse }\end{array}$ & $\begin{array}{c}201 \\
(16.8)\end{array}$ & $\begin{array}{c}110 \\
(17.6)\end{array}$ & $\begin{array}{c}91 \\
(15.8)\end{array}$ & \\
\hline \multicolumn{5}{|c|}{ Who should be screened } \\
\hline Males & $\begin{array}{l}43 \\
(2.8)\end{array}$ & $\begin{array}{c}35 \\
(4.1)\end{array}$ & $\begin{array}{c}8 \\
(1.2)\end{array}$ & \multirow{3}{*}{$<0.001$} \\
\hline Females & $\begin{array}{c}68 \\
(4.4)\end{array}$ & $\begin{array}{l}51 \\
(6)\end{array}$ & $\begin{array}{c}17 \\
(2.5)\end{array}$ & \\
\hline Both & $\begin{array}{l}1,430 \\
(92.8)\end{array}$ & $\begin{array}{c}767 \\
(89.9)\end{array}$ & $\begin{array}{c}663 \\
(96.4)\end{array}$ & \\
\hline \multicolumn{5}{|c|}{ Components of PMS } \\
\hline $\begin{array}{l}\text { Physical } \\
\text { examination }\end{array}$ & $\begin{array}{l}50 \\
(3.2)\end{array}$ & $\begin{array}{c}39 \\
(4.6)\end{array}$ & $\begin{array}{l}11 \\
(1.6)\end{array}$ & \multirow{4}{*}{$<0.001$} \\
\hline Blood tests & $\begin{array}{c}515 \\
(33.4)\end{array}$ & $\begin{array}{c}251 \\
(29.4)\end{array}$ & $\begin{array}{c}264 \\
(38.4)\end{array}$ & \\
\hline $\begin{array}{l}\text { Both physical } \\
\text { examination } \\
\text { and blood } \\
\text { tests }\end{array}$ & $\begin{array}{c}620 \\
(40.2)\end{array}$ & $\begin{array}{c}336 \\
(39.4)\end{array}$ & $\begin{array}{c}284 \\
(41.3)\end{array}$ & \\
\hline Don't know" & $\begin{array}{c}356 \\
(23.1)\end{array}$ & $\begin{array}{c}227 \\
(26.6)\end{array}$ & $\begin{array}{c}129 \\
(18.8)\end{array}$ & \\
\hline \multicolumn{5}{|c|}{ Disorders targeted by PMS } \\
\hline $\begin{array}{l}\text { Genetic } \\
\text { disorders }\end{array}$ & $\begin{array}{c}275 \\
(17.8)\end{array}$ & $\begin{array}{c}144 \\
(16.9)\end{array}$ & $\begin{array}{l}131 \\
(19)\end{array}$ & \multirow{4}{*}{0.004} \\
\hline $\begin{array}{l}\text { Sexually } \\
\text { transmitted } \\
\text { diseases }\end{array}$ & $\begin{array}{l}149 \\
(9.7)\end{array}$ & $\begin{array}{c}96 \\
(11.3)\end{array}$ & $\begin{array}{c}53 \\
(7.7)\end{array}$ & \\
\hline Both & $\begin{array}{c}922 \\
(59.8)\end{array}$ & $\begin{array}{c}489 \\
(57.3)\end{array}$ & $\begin{array}{c}433 \\
(62.9)\end{array}$ & \\
\hline Don't know* & $\begin{array}{c}195 \\
(12.7)\end{array}$ & $\begin{array}{c}124 \\
(14.5)\end{array}$ & $\begin{array}{c}71 \\
(10.3)\end{array}$ & \\
\hline
\end{tabular}

PMS = premarital screening. "Not included in the statistical analysis. ${ }^{+}$Missing data were not included in the statistical analysis.
In contrast, only 139 students (9\%) thought that it is unimportant to undergo PMS and 125 students (8.1\%) were not in favour of carrying out PMS. Of those who disagreed with PMS, 58 students (46.4\%) did not want to interfere with God's will, were afraid that the screening results would not be in favour of their partner selection (32\%), feared social stigma (19.2\%) and family refusal to continue the marriage (16.8\%). A minority were concerned that positive screening results would prevent continuation of the marriage or cause personal insult (15.2\% each) [Table 3].

Most students (87.9\%) agreed that the most appropriate time to undergo PMS would be before marriage. Some thought that the appropriate time would be during high school $(8.8 \%)$ or after marriage (3.4\%). Over one-third of the students (36.6\%) would proceed with marriage despite positive PMS test results as they believe in God's will and some (28.2\%) would make a decision based on the probability of disease. A smaller number of students indicated that they would not know what to do (17.4\%), while others would either end the engagement (10\%), proceed with marriage for emotional reasons $(6.6 \%)$ or proceed because of family pressure (1.2\%) [Table 3].

Over half of the students (55.3\%) wanted PMS to be mandatory before marriage while $26.5 \%$ were neutral and $18.2 \%$ disagreed with making PMS mandatory. More than one-third of the students (38.3\%) agreed that there should be laws and regulations to stop marriage in cases of positive PMS results, while the rest of the students were either neutral (33\%) or disagreed (28.7\%) [Table 3].

Statistical analysis to determine associations between students' sociodemographic characteristics and attitudes towards PMS showed a significant association between students' attitudes towards PMS and their gender, if their parents were related and a positive family history of hereditary diseases. Significantly more female students thought that carrying out PMS is important $(P=0.016)$ and were in favour of making PMS mandatory before marriage $(P=0.002)$ compared to male students. Females were also more likely to support the creation of laws and regulations to stop marriages in case of positive PMS tests $(P=0.010)$. Students whose parents were related were significantly more in support of making PMS manadatory before marriage $(P=0.018)$ and creating laws and regulations to stop marriages in case of positive PMS results $(P=0.020)$. Participants with a family history of hereditary blood disorders were signficantly more likely to see PMS as important $(P=0.001)$; however, they were 
Table 3: Attitudes of high school students towards Oman's premarital screening programme $(\mathrm{N}=1,541)$

\begin{tabular}{|c|c|c|c|c|}
\hline \multirow[t]{2}{*}{ Attitudes } & \multicolumn{3}{|c|}{ n (\%) } & \multirow[t]{2}{*}{$P$ value } \\
\hline & Total & $\begin{array}{c}\text { Male } \\
(\mathrm{n}=853)\end{array}$ & $\begin{array}{c}\text { Female } \\
(\mathrm{n}=688)\end{array}$ & \\
\hline \multicolumn{5}{|l|}{ Is PMS important? } \\
\hline Yes & $1,347(87.4)$ & $723(84.8)$ & $624(90.7)$ & \multirow{3}{*}{0.016} \\
\hline No & $139(9)$ & $90(10.6)$ & $49(7.1)$ & \\
\hline Don't know & $55(3.6)$ & $40(4.7)$ & $15(2.2)$ & \\
\hline \multicolumn{5}{|l|}{ Would you agree to undergo PMS? } \\
\hline Yes & $1,344(87.2)$ & $727(85.2)$ & $617(89.7)$ & \multirow{3}{*}{0.032} \\
\hline No & $125(8.1)$ & $78(9.1)$ & $47(6.8)$ & \\
\hline Don't know & $72(4.7)$ & $48(5.6)$ & $24(3.5)$ & \\
\hline \multicolumn{5}{|l|}{ Reasons for agreeing to undergo PMS* } \\
\hline To prevent transmission of diseases to my offspring & $801(73.4)$ & $421(69.1)$ & $380(78.8)$ & $<0.001$ \\
\hline To ensure that my partner is healthy & $476(43.6)$ & $298(48.9)$ & $178(36.9)$ & $<0.001$ \\
\hline To prevent transmission of diseases to me & $276(25.3)$ & $137(22.5)$ & $139(28.8)$ & 0.020 \\
\hline To ensure fitness for marriage & $208(19.1)$ & $119(19.5)$ & $89(18.5)$ & 0.710 \\
\hline \multicolumn{5}{|l|}{ Reasons for disagreement with PMS* } \\
\hline I don't want to interfere with God's will & $58(46.4)$ & $38(49.4)$ & $20(41.7)$ & 0.561 \\
\hline Afraid that the test results will not be in favour of my marital choice & $40(32)$ & $21(27.3)$ & $19(39.6)$ & 0.190 \\
\hline Leads to social stigma & $24(19.2)$ & $15(19.5)$ & $9(18.8)$ & 1.000 \\
\hline Family will refuse continuation of marriage & $21(16.8)$ & $10(13)$ & $11(22.9)$ & 0.213 \\
\hline Afraid that the positive results will prevent continuation of marriage & $19(15.2)$ & $15(19.5)$ & $4(8.3)$ & 0.161 \\
\hline Such test results are an insult to me & $19(15.2)$ & $9(11.7)$ & $10(20.8)$ & 0.241 \\
\hline \multicolumn{5}{|l|}{ Most appropriate timing of PMS } \\
\hline During high school & $135(8.8)$ & $94(11)$ & $41(6)$ & \multirow{3}{*}{$<0.001$} \\
\hline Before marriage & $1,354(87.9)$ & $716(83.9)$ & $638(92.7)$ & \\
\hline After marriage & $52(3.4)$ & $43(5)$ & $9(1.3)$ & \\
\hline \multicolumn{5}{|l|}{ Response to PMS if you were told that your children could be affected } \\
\hline Continue with engagement and marriage because I believe in God & $564(36.6)$ & $366(42.9)$ & $198(28.8)$ & \multirow{6}{*}{$<0.001$} \\
\hline Decision will depend on the probability of getting the disease & $435(28.2)$ & $209(24.5)$ & $226(32.8)$ & \\
\hline Cancel/discontinue the engagement & $154(10)$ & $62(7.3)$ & $92(13.4)$ & \\
\hline Proceed with marriage due to emotional reasons & $102(6.6)$ & $59(6.9)$ & $43(6.3)$ & \\
\hline Proceed with marriage due to family pressure & $18(1.2)$ & $13(1.5)$ & $5(0.7)$ & \\
\hline I wouldn't know what to do & $268(17.4)$ & $144(16.9)$ & 124. (18) & \\
\hline \multicolumn{5}{|l|}{ Level of agreement with making PMS mandatory } \\
\hline Agree & $852(55.3)$ & $438(51.3)$ & $414(60.2)$ & \multirow{3}{*}{0.010} \\
\hline Neutral & 408 (26.5) & $245(28.7)$ & $163(23.7)$ & \\
\hline Disagree & $281(18.2)$ & $170(19.9)$ & $111(16.1)$ & \\
\hline \multicolumn{5}{|c|}{ Level of agreement with putting laws and regulations in place to stop marriages in case of positive PMS results } \\
\hline Agree & $590(38.3)$ & $302(35.4)$ & $288(41.9)$ & \multirow{3}{*}{0.003} \\
\hline Neutral & 509 (33) & $283(33.2)$ & $226(32.8)$ & \\
\hline Disagree & $442(28.7)$ & 268 (31.4) & $174(25.3)$ & \\
\hline
\end{tabular}

PMS = premarital screening. "Percentages do not add up to $100 \%$ as participants could choose multiple responses. 
Table 4: High school students' attitudes towards premarital screening by sociodemographic characteristics $(\mathrm{N}=1,541)$

\begin{tabular}{|c|c|c|c|c|c|c|}
\hline \multirow[t]{2}{*}{ Variables* } & \multicolumn{2}{|c|}{$\begin{array}{l}\text { Agreed that carrying out } \\
\text { PMS is important }\end{array}$} & \multicolumn{2}{|c|}{$\begin{array}{l}\text { Agreed with making } \\
\text { PMS mandatory }\end{array}$} & \multicolumn{2}{|c|}{$\begin{array}{l}\text { Agreed with putting laws } \\
\text { and regulations in place } \\
\text { to stop marriage in case } \\
\text { of positive PMS results }\end{array}$} \\
\hline & n (\%) & $P$ value & n (\%) & $P$ value & n (\%) & $P$ value \\
\hline Participants who agreed with variable & $1,347(87.4)$ & - & $852(55.3)$ & - & $590(38.3)$ & - \\
\hline \multicolumn{7}{|l|}{ Gender } \\
\hline Male & $723(88.9)$ & 0.016 & $438(51.3)$ & 0.002 & 302 (35.4) & 0.010 \\
\hline Female & $624(92.7)$ & & $414(60.2)$ & & $288(41.9)$ & \\
\hline \multicolumn{7}{|l|}{ Consanguineous parents } \\
\hline Yes & $551(92.4)$ & 0.245 & $357(57)$ & 0.018 & $266(42.5)$ & 0.020 \\
\hline No & $697(90.5)$ & & $435(55.1)$ & & $284(35.9)$ & \\
\hline \multicolumn{7}{|l|}{ Personal history of hereditary disease } \\
\hline Yes & $111(94.9)$ & 0.127 & $74(58.7)$ & 0.391 & $41(32.5)$ & 0.113 \\
\hline No & $1,051(90.1)$ & & $671(55.7)$ & & $488(40.5)$ & \\
\hline \multicolumn{7}{|l|}{ Family history of hereditary disease } \\
\hline Yes & $405(94.2)$ & 0.001 & $257(57.9)$ & 0.732 & $164(36.9)$ & 0.336 \\
\hline No & $604(87.7)$ & & $399(55.6)$ & & $296(41.3)$ & \\
\hline
\end{tabular}

"Missing data were not included in the statistical analysis.

not signficantly more likely to approve of either making PMS mandatory $(P=0.732)$ or having laws and regulations to stop marriages in case of positive PMS results $(P=0.336)$ [Table 4].

\section{Discussion}

Oman's PMS programme is offered free of charge to all Omani couples planning to get married. However, the programme is not popular and its utilisation is low. ${ }^{8,9}$ Various factors contribute to this low utilisation, such as lack of public awareness and failure to make the programme legally mandatory. In addition, the role of healthcare teams in cases of positive PMS results is ambiguous. Implementing clear policies and guidelines with a comprehensive description of the roles of all stakeholders will eventually strengthen the programme. Clear roles and explicit policies in combination with legal reinforcement have been reported in Bahrain and Cyprus and have successfully contributed to reducing the incidence of inherited blood disorders. ${ }^{12,19}$

The current study showed that most students were aware of the availability of the PMS programme in Oman. However, their knowledge about what the programme includes and what diseases it targets was insufficient. More than half of the participants believed that PMS targets both genetic blood disorders and STDs and less than 20\% knew that it tests for genetic blood disorders only. These findings are fairly similar to other studies conducted in Oman and the Arab world. ${ }^{13,14,16,20,21}$ Factors contributing to this finding include age, lack of information in school curricula as well as insufficient information from school health programmes and primary healthcare facilities. With lack of guidance from healthcare officials, students indicated obtaining most of their knowledge from families, friends, media and newspaper reports. Unfortunately, healthcare service providers and school nurses were only the fourth most important source of information on PMS, which is similar to the findings of AlFarsi et al's study. ${ }^{14}$ Therefore, the role of healthcare providers in raising awareness through health education and disseminating information about PMS is an essential one.

The vast majority of participants appreciated the importance of PMS and favoured PMS testing. This was based on their desire to prevent transmission of disease to their offspring and revealed that the participants had a good understanding of the preventative role of PMS. This finding is similar to those reported in other Arab countries. ${ }^{13,14,16,20,21}$ On the other hand, a few participants were not willing to undergo PMS screening as they did not want to interfere with God's will. In addition, they indicated that they were afraid that the screening results may not be in favour of their choices or may lead to social stigma. Many studies in the Arab world have reported similar results, indicating a lack of knowledge and students' misunderstanding 
of the importance of PMS. ${ }^{13,14,21,22}$ Therefore, misinterpretation of religious beliefs necessitates the involvement of religious leaders in future awareness campaigns.

Most students agreed that the most appropriate time to carry out PMS is before marriage. However, it was alarming that more than one-third of the participants indicated that they would proceed with marriage in spite of positive PMS results due to religious beliefs, emotional reasons or family pressure. Approximately one-quarter reported that their decision would be based on the probability of transmitting the disease to their children, indicating that students consider PMS as an adjunct and not an essential step to completing the marriage process.

More than half of the participants agreed that PMS screening should be mandatory and more than onethird were in favour of laws and regulations to prevent marriage in case of positive PMS results. This finding is similar to other studies conducted in Oman, yet lower than results from Saudi Arabia where 85\% agreed that PMS should be mandatory and 63\% favoured developing legal restrictions on marriage in case of positive PMS results. ${ }^{13,14,21}$ Traditionally, the decision to marry in Oman is not limited to the couple's choice alone; familial influence plays a major role in whether a couple weds. Therefore, creating a legal basis on which to prevent marriages may conflict with traditional customs. Consequently, massive campaigns and legal support would be required to improve compliance with healthcare team recommendations, especially in individuals with a family history of genetic disorders.

The current study was the first to explore knowledge and attitudes about Oman's PMS programme among local high school students. However, this study did have various limitations. It was conducted in only one governorate and the results may not be generalised to other regions of the country. Despite the fact that PMS was explained and clarified before distributing the questionnaires, it is possible that the information was not comprehended. Furthermore, it is possible that some of the participants may have been influenced by their peers while completing the questionnaires. The questionnaire used in the study did not evaluate the participants' previous personal experience with the PMS programme, which is an important variable that could have altered the findings. In addition, the current study included only younger members of the community whereas other studies have evaluated the awareness and attitudes of older individuals. A large-scale community-based study which includes all Omani governorates and various age groups would overcome some of these limitations.

\section{Conclusion}

This study showed that high school students from Al Seeb area in Muscat Governorate have good knowledge of the availability of the PMS programme and a positive attitude towards the programme but lacked knowledge about the diseases it targets. Although the majority of respondents agreed that they would undergo PMS, only half indicated that PMS should be mandatory before marriage and just one-third agreed on the importance of laws and regulations to stop marriage in case of positive PMS test results. These findings highlight the need to increase students' awareness of and improve their knowledge and attitudes towards Oman's PMS programme. It is of utmost importance that healthcare services embed a well-structured health-related programme within a schools' curricula. A school-based programme should go hand-in-hand with a communitybased health education programme. Various means of communication can be utilised to circulate important information among the target population. Such efforts might focus on disseminating information through mass media, for example through popular and readily available social media platforms. Awareness campaigns should extend to the community and involve family members and friends. Religious leaders and lawmakers are also important contributors and can help to increase compliance and utilisation of the PMS programme.

\section{CONFLICT OF INTEREST}

The authors declare no conflict of interest.

\section{FUNDING}

This project was funded by an internal grant from the College of Nursing at Sultan Qaboos University, Muscat, Oman (Project code: IG/CON/CMHD/16/01).

\section{References}

1. Teebi AS. Genetic Disorders Among Arab Populations, 2nd ed. New York, USA: Springer, 2010. P. 7-8.

2. World Health Organization. World Health statistics 2013. From: www.who.int/gho/publications/world_health_statistics/ EN_WHS2013_Full.pdf Accessed: Apr 2019.

3. World Health Organization. Community control of genetic and congenital disorders. Regional Office for the Eastern Mediterranean: World Health Organization. From: http://apps.who. int/iris/bitstream/handle/10665/119571/dsa21.pdf?seq uence=1\&isAllowed $=y$ Accessed: Apr 2019.

4. Al-Riyami A, Ebrahim GJ. Genetic Blood Disorders Survey in the Sultanate of Oman. J Trop Pediatr 2003; 49:11-20.

5. Hamamy HA. Oman: A model for the integration of community genetic services into primary health. From: http://pdfs.semanticscholar.org/50e2/1afdb1db76a ddc78f5a73e1db98b044607ef.pdf Accessed: May 2019. 
6. Islam M. M. The practice of consanguineous marriage in Oman: Prevalence, trends and determinants. J Biosoc Sci 2012; 44:571-94. https://doi.org/10.1017/S0021932012000016.

7. Hamamy H, Antonarakis SE, Cavalli-Sforza LL, Temtamy S, Romeo G, Kate LP, et al. Consanguineous marriages, pearls and perils: Geneva International Consanguinity Workshop Report. Genet Med 2011; 13:841-7. https://doi.org/10.1097/ GIM.0b013e318217477f.

8. Oman Ministry of Health. Premarital testing and counseling guidelines, 1st ed. Department of Women and Child Health, Directorate General of Primary Health Care. Muscat, Oman: Ministry of Health, 2018. P. 8-12.

9. United Nation Fund for Population Activities (UNFPA). Preconception care mission, Oman. Gulf Cooperation Council. From: https://countryoffice.unfpa.org/gcc/2014/06/24/10005/ preconception_care_mission_oman/ Accessed: Apr 2019.

10. Karimi M, Jamalian N, Yarmohammadi H, Askarnejad A, Afrasiabi A, Hashemi A. Pre-marital screening for beta-thalassaemia in Southern Iran: Options for improving the programme. J Med Screen 2007; 14:62-6. https://doi.org/10.1258/09 6914107781261882.

11. Saffi M, Howard N. Exploring the effectiveness of mandatory premarital screening and genetic counselling programs for $\beta$-thalassaemia in the Middle East: A scoping review. Public Health Genomics 2015; 18:193-203. https://doi.org/10.1159/0 00430837.

12. Al Arrayed S. Campaign to control genetic blood diseases in Bahrain. Community Genet 2005; 8:52-5. https://doi.org/10.1 $159 / 000083340$

13. Al Kindi R., Al Rujaibi S, Al Kendi M. Knowledge and attitude of university students towards premarital screening program. Oman Med J 2012; 27:291-6. https://doi.org/10.5001/omj.20 12.72
14. Al-Farsi OA, Al-Farsi YM, Gupta I., Ouhtit A, Al-Farsi KS, Al-Adawi S. A study on knowledge, attitude, and practice towards premarital carrier screening among adults attending primary healthcare centers in a region in Oman. BMC Public Health 2014; 14:380. https://doi.org/10.1186/1471-2458-14-380.

15. Abdel-Meguid N, Zaki MS, Hammad SA. Premarital genetic investigations: Effect of genetic counselling. East Mediterr Health J 2000; 6:652-60.

16. Eshra DK, Dorgham LS, el-Sherbini AF. Knowledge and attitudes towards premarital counselling and examination. J Egypt Public Health Assoc 1989; 64:1-15.

17. Gharaibeh H, Mater FK. Young Syrian adults' knowledge, perception and attitudes to premarital testing. Int Nurs Rev 2009; 56:450-5. https://doi.org/10.1111/j.1466-7657.2009.00736.x.

18. Alkhaldi SM, Khatatbeh MM, Berggren VE, Taha HA. Knowledge and attitudes toward mandatory premarital screening among university students in North Jordan. Hemoglobin 2016; 40:1-7. https://doi.org/10.3109/03630269.2015.1135159.

19. Bozkurt G. Results from the north Cyprus thalassemia prevention program. Hemoglobin 2007; 31:257-64. https://doi. org/10.1080/03630260701297204.

20. Al-Aama JY, Al-Nabulsi BK, Alyousef MA, Asiri NA, Al-Blewi SM. Knowledge regarding the national premarital screening program among university students in western Saudi Arabia. Saudi Med J 2008; 29:1649-53.

21. Al-Kahtani NH. Acceptance of premarital health counseling in Riyadh city, 1417H. J Family Community Med 2000; 7:27-34.

22. Al-Khaldi YM, Al-Sharif AI, Sadiq AA, Ziady HH. Attitudes to premarital counseling among students of Abha Health Sciences College. Saudi Med J 2002; 23:986-90. 